\title{
Ovarian blood vessel occlusion as a surgical sterilization method in rats ${ }^{1}$
}

\author{
Eduardo Murakami ${ }^{I}$, Laíza Sartori de Camargo" ${ }^{\text {II }}$ Karym Christine de Freitas Cardoso ${ }^{\mathrm{III}}$, Marina Pacheco Miguel ${ }^{\mathrm{IV}}$, Denise \\ Cláudia Tavaresv, Cristiane dos Santos Honshovi, Fabiana Ferreira de Souza ${ }^{\text {VII }}$
}

DOI: http://dx.doi.org/10.1590/S0102-86502014000400001

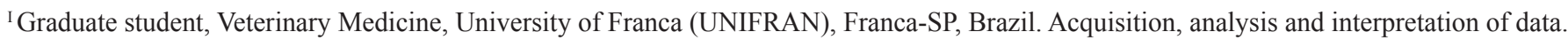

${ }^{\text {II } G r a d u a t e ~ s t u d e n t, ~ V e t e r i n a r y ~ M e d i c i n e, ~ U N I F R A N, ~ F r a n c a-S P, ~ B r a z i l . ~ A c q u i s i t i o n ~ o f ~ d a t a . ~}$

IIIMaster, Postgraduate Program in Small Animal Medicine, University of Franca (UNIFRAN), Veterinary Medicine, Franca-SP, Brazil. Acquisition, analysis and interpretation of data.

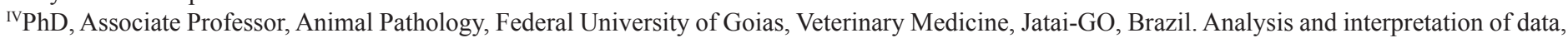
critical revision.

${ }^{\mathrm{v} F e l l o w}$ PhD Degree, Postgraduate Program in Animal Reproduction, Department of Preventive Veterinary Medicine and Animal, Reproduction, School of Agrarian Sciences and Veterinary Medicine (FCAV), Sao Paulo State University, Jaboticabal-SP, Brazil. Acquisition of data.

${ }^{V I} \mathrm{PhD}$, Full Professor, Veterinary Surgery Division, UNIFRAN, Franca-SP, Brazil. Critical revision.

VIIPhD, Full Professor, Animal Reproduction Division, UNIFRAN, Franca-SP, Brazil. Conception, design, intellectual and scientific content of the study.

\begin{abstract}
PURPOSE: To evaluate the female sterilization by occlusion of the ovarian blood flow, using the rat as experimental model.

METHODS: Fifty-five females rats were divided into four groups: I ( $n=10)$, bilateral ovariectomy, euthanized at 60 or 90 days; II ( $n=5$ ), opening the abdominal cavity, euthanized at 90 days; III $(n=20)$, bilateral occlusion of the ovarian blood supply using titanium clips, euthanized at 60 or 90 days; and IV ( $n=20)$, bilateral occlusion of the ovarian blood supply using nylon thread, euthanized at 60 or 90 days. The estrous cycle was monitored by vaginal cytology. After euthanasia, the reproductive tissues were evaluated histologically.

RESULTS: Ovarian atresia was identified macroscopically at 60 days after surgery in the rats in groups III and IV; however, most of the rats in group III maintained cyclicity. Histology of the tissues from group IV revealed that the ovarian tissue was replaced by dense fibrous connective tissue that was slightly vascularized and that intact follicles were absent by 90 days.

CONCLUSION: Ovarian blood vessels occluded caused ischemia, leading to progressive tissue necrosis, and bilateral occlusion using a nylon ligature is a viable method for surgical sterilization.
\end{abstract}

Key words: Castration. Ovariectomy. Rats. 


\section{Introduction}

Canine overpopulation and stray dogs are worldwide problems, especially in medium and low human development index (HDI) than high-HDI countries ${ }^{1}$. Free-roaming dogs are primarily responsible for zoonotic disease transmission, attacks and bites, and may be involved in automobile accidents. In most countries, dogs represent the main species abandoned on the streets, which is against the laws of animal welfare. Thus, preventing the reproduction of this species will prevent its overpopulation. Indeed, continuous sterilization can decrease the canine population density ${ }^{2}$.

Different sterilization techniques have been described but the ideal procedure should be low-cost, rapid, minimally invasive, minimally painful and considerate of animal welfare.

The most widespread technique for overpopulation control is ovariohysterectomy $(\mathrm{OVH})$, either using Snook hook, although ovariectomy (OV) is an easier technique ${ }^{3}$. Nevertheless, the OVH using Snook hook entails complications regarding the ovarian pedicle, uterine bleeding and ligature or trauma to ureter ${ }^{4,5}$, particularly when the technique is performed by an inexperienced surgeon and when small incisions are used ${ }^{4}$.

The OV is mistakenly considered a technique that produces more complications, particularly those related to the occurrence of pyometra, due to not removing the uterus. Howe ${ }^{6}$ and DeTora et al. ${ }^{3}$ reviewed the surgical techniques and concluded that OV has fewer complications than OVH.

Similar to OV, ovarian pedicle occlusion with a latex ring has been used to sterilize cattle. The surgical time was eight minutes ${ }^{7}$ after the animal was restrained. Other studies have demonstrated the feasibility and absence of complications of using this technique in cows ${ }^{8}$, although Silva et al..$^{9}$ reported edema, peritonitis, abscesses and suture dehiscence. In these studies, macroscopic examination revealed atrophic ovaries with a rigid consistency ${ }^{7}$.

Sterilization using the technique of occluding the ovarian circulation without excising the ovarian tissue has not been reported in other species nor have its histological effects on ovarian tissue. Thus, this study aimed to evaluate the macroscopic and microscopic alterations of ovarian and uterine tissue, the vaginal cytology, and the complications during and after occlusion of the ovarian blood vessels with a titanium clip or a nylon ligature to promote sterilization without ovariectomy, using the rat as the experimental model.

\section{Methods}

The study was conducted in accordance with ethical guidelines recommended by National Council for Control of
Animal Experimentation and College of Animal Experimentation, and was approved by the Institution's Animal Care and Experimentation Ethics Committee on protocol number 027/09 and complement 015/11.

Fifty-five adult ( $>80$ days old) female Wistar rats (Rattus norvegicus albinus) weighing approximately $250 \mathrm{~g}$ were used. The rats were housed in polypropylene plastic boxes $(41 \times 34 \times 16 \mathrm{~cm})$ at a density of five rats/box and in individual boxes $(30 \times 19 \times 13$ $\mathrm{cm}$ ) during the 7-day postoperative period. The animals received commercial food and water ad libitum. The rats were maintained under conditions of natural light and humidity at the ambient temperature (mean of $25^{\circ} \mathrm{C}$ ). The females were divided into four experimental groups, as described below. Group I ( $n=10$, positive control): bilateral ovariectomy; euthanasia of five rats each at 60 and 90 days. Group II ( $\mathrm{n}=5$, negative control): opening and closing the abdominal cavity without any procedure; euthanasia at the end of the experiment, 90 days after surgery, which were used as controls to determine the effect of stress of the procedure and the manipulations on the estrous cycle. Group III $(n=20)$ : bilateral occlusion of the ovarian blood supply using titanium clips; euthanasia at $60(\mathrm{n}=10)$ or $90(\mathrm{n}=10)$ days post-surgery. Group IV ( $\mathrm{n}=20)$ : bilateral occlusion of the ovarian blood supply with nylon; euthanasia at $60(n=10)$ or 90 days post-surgery.

\section{Surgical procedure}

The rats were anesthetized by intraperitoneal injection of $5 \mathrm{mg} \cdot \mathrm{kg}^{-1}$ of xylazine (Rompun ${ }^{\circledR}$, Bayer, Sao Paulo-SP, Brazil), 2.5 mg. $\mathrm{kg}^{-1}$ of morphine (Dolomorf ${ }^{\circledR}$, Cristalia ItapiraSP, Brazil) and $50 \mathrm{mg} \cdot \mathrm{kg}^{-1}$ of ketamine (Ketamine Agener 10\%, Agener Union - Animal Health, Embu-SP, Brazil) combined in the same syringe. After the anesthesia, all of the animals received $15 \mathrm{mg} \cdot \mathrm{kg}^{-1}$ of enrofloxacin (Baytril ${ }^{\circledR} 5 \%$, Bayer Health Care - Animal Health, Sao Paulo, Brazil) subcutaneously, 10 minutes before surgery. During surgery, the rats had an oxygen mask.

After the surgical field was prepared, a ventro-medial celiotomy was performed, using an approximately $1.5-\mathrm{cm}$ long incision, $0.5-\mathrm{cm}$ caudal to the umbilicus. Then, using a Snook hook, the ovary was located, gently lifted from the abdominal cavity, and held by the suspensory ligament using anatomical forceps. The same procedures were performed bilaterally over the ovaries.

A specific clipper (Horizon Teleflex ${ }^{\circledR}$ Ligation System, Durham, NC, USA) was used on the rats of group I (control) to apply one titanium clip (Horizon ${ }^{\mathrm{TM}}$ Ligation System, Large 
Horizon clips, Durham, NC, USA) below the ovary, involving the ovarian pedicle (mesovarium), the ovarian suspensory and proper ligaments, the mesosalpinx and the proximal third of the uterine tube. The tissue was sectioned $3 \mathrm{~mm}$ distal of the titanium clip to achieve ovarian resection.

No procedure was performed on the rats of group II, except opening the abdominal cavity and manipulating the ovarian tissue.

A titanium clip was positioned below each ovary of the rats of group III, involving the ovarian pedicle (mesovarium), the ovarian suspensory and proper ligaments, the mesosalpinx and the proximal third of the uterine tube (Figure 1); however, the ovaries were not removed from this group.

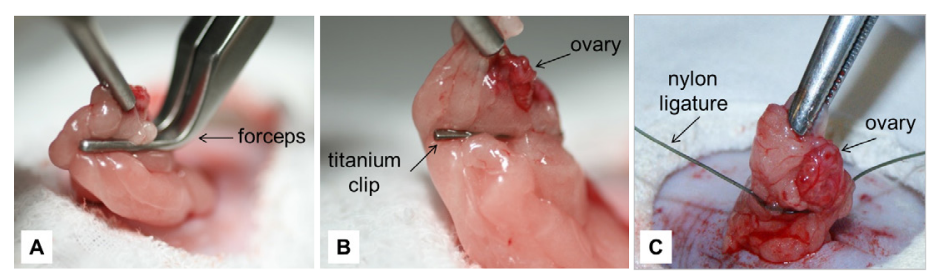

FIGURE 1 - Positioning of the titanium clip (A and B) or nylon ligature (C) to occlude the ovarian blood supply in a rat.

A ligature was placed below each ovary of the rats of group IV (in the same region as in the group III rats), using 4-0 nylon filament (Nylon monofilament, Brasuture, Sao Sebastiao da Grama-SP, Brazil), involving the ovarian pedicle (mesovarium), the ovarian suspensory and proper ligaments, the mesosalpinx and the proximal third of the uterine tube. The ovaries also remained in this group.

After surgery, the exposed tissue in all the groups was repositioned within the cavity, and the abdomen was inspected for bleeding. The musculature was closed with a continuous closure suture, using 4-0 polyglactin 910 filament (Vicryl ${ }^{\circledR}$, Ethicon, Johnson \& Johnson Medical Limited, Livingston, Scotland). The skin was sutured with 4-0 nylon filament using a simple interrupted suture.

Immediately after surgery, the rats received a subcutaneous application of $0.2 \mathrm{mg} \cdot \mathrm{kg}^{-1}$ of meloxicam $(0.2 \%$ Injectable Maxicam, Ourofino Agribusiness Ribeirao Preto, Brazil). During recovery from anesthesia, the rats remained under a heated mattress.

During the postoperative period, the rats received meloxicam at the same dosage and administration route, at 24 and 48 hours after surgery. The surgical wounds were inspected daily and treated with rifampicin (Rifocina ${ }^{\circledR}$ spray, Sanofi-
Aventis, Suzano-SP, Brazil) for seven days. The females were kept in individual boxes, and their behaviors and attitudes were evaluated, particularly their activity and intake of food and water.

\section{Vaginal cytology}

The estrous cycle was monitored by vaginal cytology. A vaginal smear was performed every 24 hours for five days before surgery, including the day of surgery. Subsequently, it was performed once a week. A sterile swab (Consalab, Sao PauloSP, Brazil) was introduced into the cranial vagina, rotated on a glass slide, air dried and stained with Diff-Quick (Laborclin, Pinewoods, PR, Brazil).

\section{Euthanasia and macroscopic evaluation}

Euthanasia was performed by intraperitoneal injection of $100 \mathrm{mg} / \mathrm{kg}$ thiopental (Thiopentax ${ }^{\circledR}$, Cristalia, Itapira-SP, Brazil) at 60 or 90 days after surgery, as described above for the various groups. The ovarian and uterine tissues were evaluated macroscopically to identify the deposition of fibrin clots and adhesions to other organs. Then, these tissues were removed from the abdominal cavity and sectioned for histological evaluation.

\section{Histological evaluation}

The ovarian and uterine sections were fixed in $10 \%$ buffered formalin for 24 hours.

The fixed fragments were dehydrated, diaphanized, and embedded in paraffin. Five-millimeter sections were stained with hematoxylin and eosin and analyzed by optical microscopy by a single evaluator.

The integrity and/or necrosis, apoptosis, degeneration, hyperemia, hemorrhage, edema, leukocyte infiltration, vascular and fibroblast proliferation and fibrous tissue formation in both the cortical and medullary region in the ovary and in all uterine layers were evaluated.

\section{Closure capacity of the titanium clip}

Although it was not the initial purpose of this study, after obtaining the results for group II, we investigated the closure capacity of the clips, to observe the center of the device after close (Figure 2). 


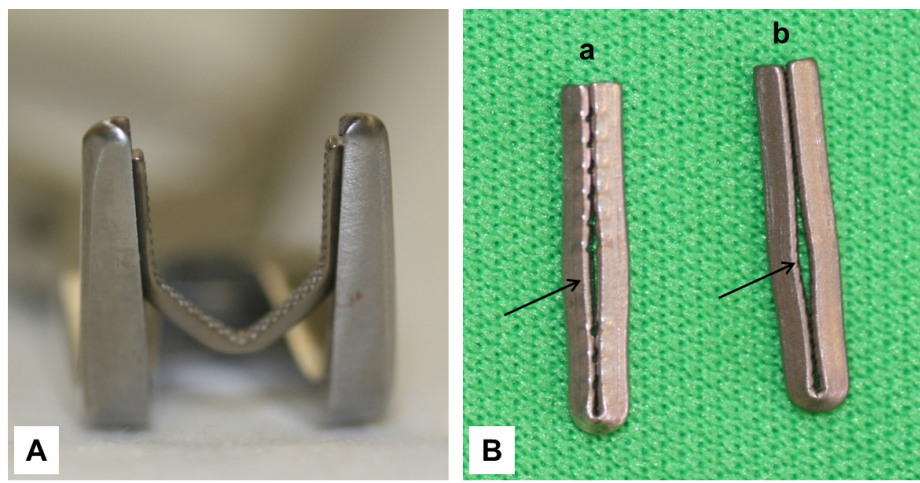

FIGURE 2 - Materials used to occlude the ovarian blood supply. A: Titanium clip held by forceps. B: Two types of titanium clips that were not completely closed in the middle region (arrows).

\section{Results}

There were no complications during surgery or post-surgery.

All of the rats exhibited normal cyclicity before surgery, as determined by vaginal cytology.

In group I (ovariectomy - positive control), four rats were in anestrus from the second week after surgery, and all of the females were in anestrus by the third week. In group II (opening and closing the abdominal cavity, with manipulation of the ovarian tissue - negative control), all of the rats maintained the estrous cycle. In group III (bilateral occlusion of the blood supply to the ovary using a titanium clip) at the end of the evaluation, three and two rats were in anestrus at 60 and 90 days post-surgery, respectively. In group IV (bilateral occlusion of the blood supply to the ovary using a nylon ligature), at 60 and 90 days postsurgery, three females and one female maintained an estrous cycle, respectively. In this group, the other females were in anestrus for at least three consecutive weeks at 90 days post-surgery.

No macroscopic ovarian and uterine alterations were noted after euthanasia, with the exception of ovarian atrophy in some of the females. There were no adhesions, abscesses or bleeding.

The histology of all groups' samples showed that the uterus contained endometrial cells and endometrial glands and had a normal myometrium.

Figure 3 shows some of the histological alterations observed in the experimental groups. The ovaries of the rats in groups I and II exhibited normal tunicae albugineae, cortical regions containing numerous follicles at different stages, normal oocytes and several well-developed corpora lutea. The medullary regions were slightly hyperemic, and the interstitial regions were normal. Discrete changes were observed in group I, such as rare necrotic foci and vacuolar degeneration of corpora lutea, discrete

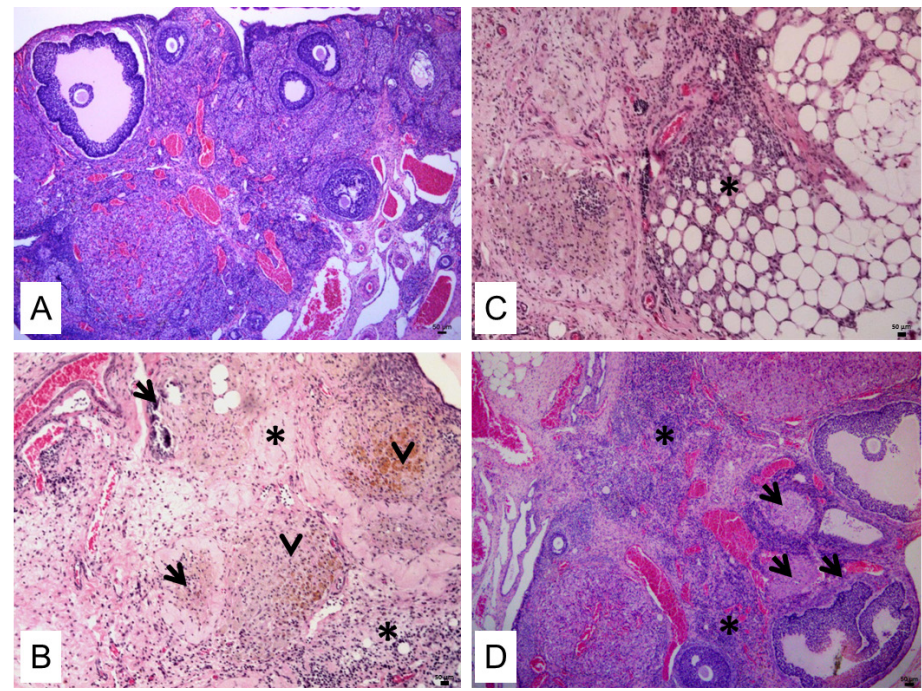

FIGURE 3 - Histology of ovarian tissue from the rats. A: Group I (90 days), normal tunica albuginea and a cortical region with numerous follicles at different stages, normal oocytes and several well-developed corpora lutea. There is mild hyperemia and mild edema in the interstitial regions; HE, x50. B: Group IV (90 days), ovarian tissue was replaced by dense fibrous connective tissue that is slightly vascularized (*), fibrotic corpora lutea and a corpus luteum containing hemosiderin (arrowhead), calcified and atretic follicles (arrows); HE, x50. C: Group IV (90 days), infiltration of adjacent adipose tissue $(*)$ in atrophied ovarian tissue; HE, x50. D: Group III (90 days), in the cortical region, there is severe diffuse congestion and coagulation necrosis of entire follicles or portions of follicles that have disorganized follicular cells (arrows), some normal follicles and moderate proliferation of fibrovascular tissue and inflammatory infiltrates $(*)$; HE, x50.

necrosis of the granulosa cells in growing follicles and mild edema in the interstitial regions. Furthermore, rare central bleeding (corpus hemorrhagicum) and submesothelial hemorrhages were observed in the corpora lutea.

The ovarian tissue of group III displayed prominent ischemic changes and fewer components in the cortex (obvious reduction of the number of primordial primary and secondary follicles and corpora lutea, particularly at 90 days) and medulla. In addition, normal follicles and corpora lutea were observed. However, several follicles demonstrated coagulation necrosis, and the granulosa and luteinic cells showed vacuolar degeneration, necrosis and apoptosis. Sometimes, granulosa cells were observed detached from the basal membrane, and hemorrhages were seen in the centers of corpora lutea. In the interstitial region, there was moderate bleeding, mild to moderate swelling and diffuse and marked congestion. Moderate proliferation of fibrovascular tissue was observed in both the medullary and cortical regions. The luteinic cells contained hemosiderin and several types of hemosiderophages. The surrounding adipose tissue contained moderate multifocal mononuclear infiltrates and a few giant cells. 
In group IV, 19 samples showed that the ovarian tissue had been replaced by slightly vascularized dense fibrous connective tissue. In four rats, rare corpora lutea containing hemosiderin, secondary follicles undergoing degeneration, and calcified and atresic follicles were observed. Only one animal showed remnants of normal ovarian tissue. Five animals exhibited calcified follicles and necrotic corpora lutea, and two animals showed degenerated secondary follicles, necrosis and calcification. Considerable amounts of surrounding adipose tissue with multifocal mononuclear infiltrates, giant cells and fibrovascular tissues were found.

\section{Discussion}

The histological changes observed in the ovaries of the rats in groups I and II were discrete and related to the surgery. In group III, in which a titanium clip was used, ischemic changes evolved from 60 to 90 days post-surgery, and the ovarian tissue was progressively reduced, exhibiting decreased numbers of follicles and corpora lutea and areas of fibrovascular tissue. Nevertheless, the remaining cortex showed slight to nonexistent degenerative changes. Thus, until 90 days post-surgery, the clip did not cause atrophy or total destruction of the ovarian tissue. These results were confirmed by vaginal cytology, which showed that most of the females were in diestrus or proestrus at 90 days after surgery.

After closing several types of clips, we found that the center of the device retained a gap of a few millimeters. A large sized clip was used in this study because of the abundant amount of adipose tissue in the rat ovarian pedicle, which prevented the use of smaller clips. Dissecting the tissues to identify blood vessels and facilitate the placement of small clips was considered; however, this procedure was not practical and inconsistent with the purpose of the study, which was a rapid, safe surgery. In this group, the ovaries were partially destroyed and germinal tissue was replaced by fibrovascular and adipose tissue by the time of the evaluation. These results confirmed our hypothesis of the partial closure of the clips on the tissues.

Ovarian tissue contains angiogenic factors that stimulate endothelial cell migration ${ }^{10,11}$, allowing tissue revascularization when heterologous or autologous ovarian grafting is performed ${ }^{12-14}$ However, in this study, ischemic tissue injury persisted during the evaluation period, and revascularization was not observed upon histological evaluation.

In group IV, in which a nylon ligature was used to occlude the ovarian vessels, anestrus and gross ovarian atrophy occurred in most of the rats, indicating the absence of circulation in the tissue, which is consistent with the findings of other studies in cattle 7,9 that used similar techniques. These results were supported by the histological evaluation, which showed that ovarian tissue had been replaced by fibrous connective tissue. This finding indicates that the methods of obstruction caused progressive ischemia and tissue necrosis, particularly at 90 days. However, at 60 days, five females exhibited remnants of ovarian tissue, and one had ovarian tissue with little damage. In this period, there most likely was not sufficient time for tissue atrophy due to vessel occlusion. At 90 days, only one female had ovarian tissue with a few injuries, which may be related to a technical mistake.

There were no postoperative complications in the rats, as reported by Silva et al. ${ }^{9}$ in cows sterilized by placing a latex ring around the ovarian pedicle, such as edema, peritonitis, abscesses and suture dehiscence. Such complications were not observed in this study most likely because the procedures were performed in a surgical operating room using all of the principles of asepsis and antisepsis, which reduced the risk of infection.

Meirelles et al. ${ }^{15}$ reported weight loss when a latex ring was placed around the ovarian pedicle of cows, which was due to pain. In this study, the behavior and food intake did not change post-surgery, most likely due to the use of anti-inflammatory medication during the postoperative period, which was not mentioned by Meirelles et al. ${ }^{15}$. Moreover, the rats were monitored during the anesthesia recovery period and for days, and no signs of pain were observed, as described by Roughan and Flecknell ${ }^{16}$, such as back arching, falling/staggering, dorsal muscle spasms, writhing, licking of wounds and lack of movement.

Sterilization without removing the female reproductive tract is safer than $\mathrm{OVH}$, with a lower risk of hemorrhage, reduced surgical time and lower costs. This procedure presented in this study is equivalent to $\mathrm{OV}$, which is more advantageous than $\mathrm{OVH}^{17,18}$, and does not require the removal of portions of the reproductive tract. Meirelles et al. ${ }^{15}$ used a similar technique in cattle and observed the absence of estrus during the evaluation period due to ovarian degeneration, consistent with the findings of the vaginal cytology in this study, particularly when we consider group IV.

Moreover, OV does not cause the post-surgical effects observed after $\mathrm{OVH}^{6,18}$, since uterine tissue is healthy. Using a Snook hook in the technique proposed in this study would facilitate the procedure and reduce the surgical time and cost, with minimal risk in sterilizations to control overpopulation. Besides sterilization benefits to population control and disease transmission, sterilized animals have a greater lifespan than intact $\operatorname{dogs}^{19}$.

Furthermore, the histopathological findings confirmed that occlusion of the blood vessels using nylon thread promoted tissue loss earlier than did occlusion using titanium clips. In the 
group treated with the titanium clips, there was still functional ovarian tissue and young scar tissue at 90 days post-surgery, indicating that tissue loss due to ischemia had occurred slowly. In contrast, the nylon ligature caused the total replacement of the ovarian tissue by fibrous scar tissue by 90 days post-surgery.

The occlusion of blood supply, an easier technique can be important to free roaming dogs sterilization due their lifestyle (life with other dogs, shorter lifespan, poorer health, free to reproduce) and because the contraceptives are not $100 \%$ effectives $^{20}$.

\section{Conclusion}

The occlusion of the ovarian vessels can be an alternative to surgical sterilization, and similar the ovariectomy, with minimal post-surgical risk, a minimal incision and rapid recovery of the subjects, with minimal complications, particularly when nylon ligatures are used for the occlusion.

\section{References}

1. Dalla-Villa P, Kahn S, Stuardo L, Iannetti L, Di Nardo A, Serpell JA. Free-roaming dog control among OIE-member countries. Prev Vet Med. 2010;97:58-63.

2. Amaku M, Dias RA, Ferreira F. Dinâmica populacional canina: potenciais efeitos de campanhas de esterilização. Rev Panam Salud Publica. 2009;25:300-4.

3. DeTora M, McCarthy RJ. Ovariohysterectomy versus ovariectomy for elective sterilization of female dogs and cats: is removal of the uterus necessary? JAMA. 2011;239:1409-12.

4. Santos FC, Corrêa TP, Rahal SC, Crespilho AM, Lopes MD, Mamprim MJ. Complicações da esterilização cirúrgica de fêmeas caninas e felinas. Revisão da literatura. Vet Zootec. 2009;16:8-18.

5. Honsho CS, Honsho DK, Gerardi DG, Canola JC, Bolzan AA, Souza FF. Manifestação incomum de paralisia de membros pélvicos em felino com hidronefrose decorrente de ovarioectomia. Relato de caso. ARS Vet. 2010;26:1-5.

6. Howe LM. Surgical methods of contraception and sterilization. Theriogenology. 2006;66:500-9.

7. Silva LAF, Pales AP, Fioravanti MCS, Pádua JT, Silva OC, Santos KJG. Anel de látex aplicado no pedículo ovariano de bezerras Nelore. Acta Sci Anim Sci. 2006;28:97-103.

8. Cain DVJR. Do different spay techniques and growth implant frequencies affect weight gain in heifers. Vet Med. 1986;81:464-88.

9. Silva LAF, Almeida CF, Viana-Filho PRL, Veríssimo ACC, Rabelo RE, Eurides D, Fioravanti MCS. Descrição de duas técnicas cirúrgicas para castração de fêmeas bovinas e avaliação do pósoperatório. Cienc Anim Bras. 2004;5:47-53.

10. Nisolle M, Casanas-Roux F, Qu J, Motta P, Donnez J. Histologic and ultrastructural evaluation of fresh and frozen-thawed human ovarian xenografts in nude mice. Fertil Steril. 2000;74:122-9.

11. Weissman A, Gotlieb L, Colgan T, Jurisicova A, Greenblatt EM, Casper RF. Preliminary experience with subcutaneous human ovarian cortex transplantation in the NOD-SCID mouse. Biol Reprod. 1999;60:1462-7.
12. Brito NMB, Torres IO, Silveira EL, Santos LLT. Estudo da viabilidade do enxerto de ovário na bolsa omental de ratos utilizando ciclosporina A. Acta Cir Bras. 2005;20:174-9.

13. Petroianu A, Alberti LR, Vasconcellos LS. Histoarquitetura, função endócrina e taxa de gravidez após auto-implante ovariano ortotópico íntegro e fatiado em coelha. Rev Bras Ginecol Obstet. 2004;26:11723.

14. Petroianu A, Alberti LR, Vasconcellos LS, Leite JM, Castro LPF. Avaliação endócrina e morfológica de transplante ovariano homógeno. J Bras Patol Med Lab. 2004;40:206-11.

15. Meirelles C, Bueno Jr CF, Kozicki LE, Weiss RR, Segui MS. Avaliação do ganho de peso de novilhas ovariectomizadas por técnica transvaginal. Rev Acad Ciênc Agrár Ambient. 2007;5:303-7.

16. Roughan JV, Flecknell PA. Evaluation of a short duration behaviourbased post-operative pain scoring system in rats. Eur J Pain. 2003;7:397-406.

17. Janssens LAA, Janssens GHRR. Bilateral flank ovariectomy in the dog: surgical technique and sequelae in 72 animals. J Small Anim Pract. 1991;32:249-52.

18. Okkens AC, Kooistra HS, Nickel RF. Comparison of long-term effects of ovariectomy versus ovariohysterectomy in bitches. J Reprod Fertil Suppl. 1997;51:227-31.

19. Hoffman JM, Creevy KE, Promislow DEL. Reproductive capability is associated with lifespan and cause of death in companion dogs. Plos One. 2013;8:1-7.

20. Massei G, Miller LA. Nonsurgical fertility control for managing free-roaming dog populations: a review of products and criteria for field applications. Theriogenology. 2013;80:829-38.

\section{Acknowledgement}

To Mr. José Luís de Souza, Teaching ProfessionalHistotechnologist, UNIFRAN, for his valuable work during the development of this research.

\section{Correspondence:}

Fabiana Ferreira de Souza

Departamento de Reprodução Animal e Radiologia Veterinária, FMVZ Universidade Estadual Paulista

Distrito de Rubião Junior, $\mathrm{s} / \mathrm{n}^{\mathrm{o}}$

18.618-970 Botucatu - SP Brasil

Tel.: (55-14)3880-2237

fafesouza@fmvz.unesp.br

Received: Dez 18, 2013

Review: Feb 19, 2014

Accepted: March 18, 2014

Conflict of interest: none

Financial sources: Sao Paulo Research Foundation(FAPESP-2010/00657-1 and 2009/16314-9) and National Council for Scientific and Technological Development (CNPq)

${ }^{1}$ Research performed at Veterinary Hospital, University of Franca (UNIFRAN), Franca-SP, Brazil. 